\title{
Gyerekkatonák a jemeni polgárháborúban
}

\begin{abstract}
Jemenben napjainkra humanitárius krízis alakult ki a több éve folyamatosan zajló polgárháború eredményeként. A szemben álló felek mindegyike kihasználta a kritikus életkörülményeket, a vallási-politikai meggyőződéseket, valamint a jemeni tradíciókat, amikor intenzív toborzó tevékenységet folytattak fegyveres erejük növelésére a 18 év alatti fiatalok között, súlyosan és tudatosan megsértve ezzel a vonatkozó nemzetközi előirásokat. A tanulmány célja, hogy a statisztikai adatok szemléltetése mellett részleteiben elemezze a gyerekek csatlakozásának okait, a toborzásukra alkalmazott módszereket, kiképzésüket, és bevetésüket, valamint a mindezekkel összefüggő propagandatevékenységet. A szerző kitér a kedvezőtlen folyamat megállitására tett intézkedésekre is, valamint a gyerekkatonák rehabilitációjának problematikájára és a kedvezőtlen kilátásokra, amennyiben a jelenlegi tendencia akuttá válna.
\end{abstract}

Kulcsszavak: Jemen, polgárháború, gyerekkatonák, rehabilitációs és reintegrációs lehetöségek

\section{Child Soldiers in the Yemeni Civil War}

Today, a humanitarian crisis has developed in Yemen as a result of several years of ongoing civil war. All opposing parties took advantage of critical living conditions, religious-political beliefs, and Yemeni traditions in intensive recruitment to increase their armed power among young people under the age of 18, in serious and deliberate violation of relevant international standards. The aim of the study is to provide a detailed analysis of the reasons for children joining, the methods used to recruit them, their training and deployment, and the related propaganda activities, in addition to illustrating the statistics. The author also discusses the measures taken to stop the unfavourable process, as well as the problem of rehabilitation of child soldiers and the unfavourable prospects should the current trend become acute.

Keywords: Yemen, civil war, child soldiers, rehabilitation and reintegration opportunities

„Gyerekkatonának számít minden olyan 18 év alatti személy, aki - tekintet nélkül az általa elvégzett feladat jellegére - akár reguláris, akár irreguláris fegyveres erőkben szolgál." Részlet a Fokvárosi Alapelvekből

\section{Bevezetés}

Számos nemzetközi emberi jogi törvény és egyezmény 18 évben állapítja meg a törvényesen besorozható és fegyveres ellenségeskedésben bevethető katonák minimális életkorát.

1 Prantner Zoltán a Kodolányi János Egyetem Jóléti Társadalom Intézet Nemzetközi Tanulmányok Tanszék egyetemi docense. E-mail: prantner.zoltan@kodolanyi.hu 
A 15 évesnél fiatalabb gyermekek toborzását és katonaként történő alkalmazását a nemzetközi humanitárius jog - szerződés és szokás - tiltja, és azt a Nemzetközi Büntetőbíróság háborús büncselekményként határozza meg. Ezeket a gyermekek védelmére meghirdetett irányelveket korábban Jemen is elfogadta, azonban e garanciavállalásokat semmissé tette az aktuális jemeni polgárháború.

Az országban 2014 szeptemberében válsághelyzet alakult ki, amikor az Irán által támogatott, húszi néven elhíresült síta Anszár Allah erői elfoglalták Szanaát és mellette több nagyvárost. A krízis 2015 márciusában tovább súlyosbodott, amikor a Szaúd-Arábia vezette nemzetközi koalíciós erők katonailag beavatkoztak a délre menekült, nemzetközileg elismert kormány oldalán. Az azóta eltelt időszakban a fegyveres konfliktus erőviszonyai tovább polarizálódtak, illetve új faktorok jelentkeztek. Mindezek okán jelenleg egyszerre küzdenek egymás ellen a húszik, a jemeni kormányerők, a kormánybarát Népi Ellenállás egységei, az arab koalíciós erők, az al-Káida helyi szervezete, a déli szakadár mozgalom és az egyéb különféle fegyveres csoportok.

A harcok intenzitásának növekedésével a szemben álló felek a nemzetközi előírásokat súlyosan megsértve intenzív toborzótevékenységet folytattak az ellenőrzésük alatt álló területeken élő fiatalok körében fegyveres erejük növelésének céljából. Több ezer fiú csatlakozott eddig hozzájuk ideológiai-vallási meggyőződésből, a hagyományok miatt, vagy a különféle háborús propagandák és a polgárháborús körülmények között átélt nélkülözések, valamint kényszer hatására.

\section{Szabályozások a gyerekek besorozásának korlátozására}

A II. világháború után elfogadott Genfi egyezmények, amelyek négy szerződésből és három jegyzőkönyvből állnak, meghatározzák a fegyveres konfliktusok alapvető nemzetközi jogi normáit. Az 1977-ben kelt két kiegészítő jegyzőkönyv a gyermekek jogainak védelmével foglalkozott a fegyveres összeütközésekben, amikor háborús büncselekménynek nyilvánította a 15 év alatti gyermekek katonai szolgálatra történő besorozását - függetlenül attól, hogy arra önkéntes alapon vagy kényszer hatására kerül sor - és fegyveres összecsapásban történő bevetésüket. ${ }^{2}$

Az 1997. április 27-30. között megtartott UNICEF tanácskozás Fokvárosban már kísérletet tett arra, hogy definiálja a gyerekkatonák fogalmát. Az ekkor elfogadott definíció szerint „gyerekkatonának számít minden olyan tizennyolc évnél fiatalabb személy, aki bármilyen reguláris vagy irreguláris fegyveres erő tagja bármilyen minőségben, kivéve családtagként". A meghatározás ugyanakkor nem határolta el markánsan egymástól a tényleges fegyveres szolgálatot ellátó és a kisegítő tevékenységet (például konyhai kisegítő, hordár, hírvivő vagy hírszerző) végző fiatalokat. Emellett magában foglalta azokat a lányokat is, akiket szexuális okból vagy kényszerházasság célzatával toboroztak. További vitákat generált az életkorhatár megállapítása, mivel a harmadik világ számos államában még napjainkban is gyakran a fiatalok társadalmi szerepe határozza meg, hogy hány éves koruktól

International Committee of the Red Cross: Protocols Additional to the Geneva Conventions of 12 August 1949. [online], Geneva, 2010. Forrás: icrc.org [2020. 10. 03.]

Norbert B. Wagner: Child Soldiers. [online], 2012. 07. 26. 7. Forrás: humanitaeres-voelkerrecht.de [2020. 10. 03.] 
tekintik őket felnőttnek, és ezáltal hadra foghatónak. Legvégül nem tesz említést arról a reális lehetőségről sem, hogy a gyermek effektíven fegyvert visel, vagy, hogy valamelyik fegyveres szervezethez történő csatlakozása önkéntes alapon történik.

A gyermekek jogairól 1989. november 20-án New Yorkban aláírt egyezmény megerösítette a gyerekkatonaság tilalmát. A megállapodás leszögezte, hogy minden 18 év alatti személyt gyermeknek kell tekinteni, kivéve, ha a rá vonatkozó jogszabályok alapján már betöltötte a nagykorúságot. ${ }^{4} \mathrm{~A}$ deklarált alapelvek megerősítésére 2000 májusában csatolták az okmányhoz az ENSZ Közgyülése által elfogadott, a gyermekek fegyveres konfliktusokba történő bevonásáról szóló Fakultatív jegyzőkönyvet. A dokumentum megemelte az 1977-ben megállapított életkorhatárokat, amikor kinyilvánította, hogy az önkéntes katonai szolgálat addigi 15 éves alsó korhatárát fel kell emelni 16 évre, 18 év alatt pedig megtiltotta a kötelező katonai szolgálatot. Elvárásként fogalmazta meg továbbá, hogy a fegyveres erők 18 évesnél fiatalabb tagjai ne vehessenek közvetlenül részt háborús cselekményekben. Mindezeken túl az aláíró országok elítélték az olyan célpontok közvetlen támadását, ahol gyermekek vélhetően nagy számban vannak jelen (például iskolák vagy kórházak). ${ }^{5}$

A fentiek szellemében fogadták el és vezették be Jemenben a 2002. évi 45. számú törvényt a jemeni gyermekek jogairól, aminek a 149. paragrafusa megtiltotta a 18 év alatti személyek részvételét és toborzását a fegyveres konfliktusokban. ${ }^{6} \mathrm{Az}$ ország 2007-ben csatlakozott a Fakultatív jegyzőkönyvekhez, majd a kormány 2012 decemberében jóváhagyta a fegyveres erökhöz vagy csoportokhoz kapcsolódó gyermekekre vonatkozó iránymutatásokat (az úgynevezett „párizsi elveket”) is. ${ }^{7}$ Az elfogadott és kihirdetett irányelvek ellenére azonban a kormányerők továbbra is besoroztak gyerekeket, ami a polgárháború kirobbanását követően általánosan alkalmazott gyakorlattá vált a szemben álló felek mindegyikénél.

Az ENSZ szakosított munkacsoportja 2013-tól tárgyalásokat folytatott a jemeni kormányzattal a gyermekek katonai célú alkalmazásának beszüntetésére. A megbeszélések eredményeként a szanaai vezetés közös akciótervet írt alá az ENSZ-szel 2014. május 14-én, amiben vállalta, hogy beszünteti a toborzást a fiatalok között és a gyerekkatonák alkalmazását. ${ }^{8}$ Egy hónappal később közös szakosított bizottság alakult az akciótervben foglaltak végrehajtására, illetve a folyamat nyomon követésére. A pozitív kezdeményezés azonban alig három hónapig tartott. A bizottság előbb felfüggesztette működését, miután a húszik szeptemberben elfoglalták a kormányzati épületeket a fővárosban, majd pedig a polgár-

United Nations Treaty Collection: Convention on the Rights of the Child. [online], 1989. 11. 20. Forrás: treaties.un.org [2020. 10. 03.]

Office of the United Nations High Commissioner for Human Rights: Optional Protocol to the Convention on the Rights of the Child on the involvement of children in armed conflict. [online], 2000. 05. 25. Forrás: ohchr.org [2020.10. 03.]

6 Child Soldiers International: Yemen. Report to the Committee on the Rights of the Child in advance of Yemen's initial periodic report on the Optional Protocol to the Convention on the Rights of the Child on the involvement of children in armed conflict. [online], London, 2013. 03. 4. Forrás: tbinternet.ohchr.org [2020. 10. 03.]

Child Soldiers International: Child Soldiers Global Report 2008 - Yemen. [online], 2008. 05. 20. Forrás: refworld.org [2020. 10. 02.]; Office of Special Representative of the Secretary-General for Children and Armed Conflict: Five new countries endorse the Paris Commitments to end the use of children in conflict. [online], 2012. 12. 03. Forrás: childrenandarmedconflict.un.org [2020. 10.03.]

8 UNICEF: Yemen signs action plan to end recruitment and use of children by armed forces. [online], 2014. 05. 14. Forrás: unicef.org [2020. 10.03.] 
háború eszkalálódása miatt teljesen lekerült a napirendről a megállapodás betartása jemeni részről.

Az ENSZ az elkövetkező években megpróbált külön-külön egyeztetni a szemben álló felekkel a kérdésben. Az erőfeszítések eredményeként a kormánypárti erők vezérkarfönök-helyettese 2018 márciusában parancsban emlékeztetett a gyermekek besorozásának és alkalmazásának tilalmára a jemeni fegyveres erők kötelékében. Elrendelte egyúttal azt is, hogy azonnal be kell jelenteni az illetékes hatóságoknak a kiadott utasítás bármilyen megsértését. A kormány emellett ütemtervet állított össze és írt alá 2018. december 18-án az ENSZ-szel a 2014-es egyezmény végrehajtásáról. A dokumentumban foglalt különféle rendelkezések a gyerekek besorozásának megelőzése mellett kitértek a kormányerőkhöz kapcsolódó gyermekek leszerelésére, valamint reintegrációs eljárások kidolgozására az elbocsátott fiatalok visszailleszkedésének segítésére. A deklarált elvek ellenére azonban a kormánycsapatok alig változtattak korábbi gyakorlatukon és továbbra is jelentős számban fogadtak soraikba 18 év alatti fiatalokat. ${ }^{9}$

Az ENSZ munkacsoportjának különleges képviselője széles körü együttmüködést alakított ki a kérdésben a Szaúd-Arábia vezette arab koalíciós erőkkel azt követően, hogy látogatást tett azok rijádi főhadiszállásán 2017 októberében. A korábban már bevezetett intézkedések hatékonyságának növelésére, valamint a feltárt hiányoságok kiküszöbölésére rendszeresen tartottak magas szintü szakmai találkozókat 2018-ban, 2019. március 25-én pedig egyetértési megállapodás született az ENSZ és a koalíciós erők között a jemeni gyermekek védelméröl. ${ }^{10}$

Az ENSZ folyamatos kísérletet tett arra, hogy a húszi vezetéssel is megállapodásra jusson a gyermekek jogainak betartásáról, valamint a súlyos jogsértések elkerüléséről. Az évek során jelentős előrelépés történt a kapcsolattartás terén, a sorozatos megbeszélések ellenére azonban megegyezés nem született. ${ }^{11}$

\section{Jemeni gyerekkatonák a statisztikák tükrében}

Az ENSZ Biztonsági Tanácsa kezdettől fogva kiemelt figyelmet fordított a jemeni konfliktusra. A fegyveres összecsapások alakulásának és a gyermekek helyzetének monitorozására külön munkacsoport alakult, ami az általa megfogalmazott javaslatok mellett folyamatosan rögzítette beszámolóiban a tapasztalt jogsérelmeket.

A közzétett statisztikák alapján a szembenálló felek 3034 gyermeket (3018 fiút és 16 lányt) toboroztak és alkalmaztak fegyveres szolgálatra 2013 áprilisa és 2018 decembere között. ${ }^{12}$ A beazonosított esetek alapján 1940 fő (a teljes létszám 64\%-a) a húszi

UN General Assembly Security Council: Children and armed conflict. Report of the Secretary-General. S/2019/453, 2019. [online], 2019. 06. 03. Forrás: un.org [2020. 10. 04.]

10 UN General Assembly Security Council (2019) i. m.

11 UN General Assembly Security Council (2019) i. m.

12 Az ENSZ a jemeni fegyveres konfliktus elhúzódásával megállapította, hogy a besorozott gyermekek száma a korábbi évek adataihoz viszonyítva megtöbbszöröződött. Az évekre lebontott statisztika alapján a fiatalabb generáció tagjai közül 2013 áprilisa és decembere között 91 föt, 2014-ben 156-ot, 2015-ben 915-öt, 2016-ban 606-ot, 2017-ben 896-ot, 2018-ban pedig 370-et soroztak be. Lásd UN General Assembly Security Council (2019) i. m. 
lázadókhoz - hivatalos elnevezésükkel Anszár Allahhoz - csatlakozott. ${ }^{13}$ A fiúk túlnyomó része (mintegy 83\%-uk) 15-17 év közötti tinédzser volt. Az ENSZ által megvizsgált esetek alapján megállapítható volt, hogy a síita húszik és a Népi Ellenállás csapatai akár 10 éveseket is besoroztak katonának..$^{14}$

A fiatal fiúk közül több mint 700 föt vetettek be fegyveres összecsapásokban, ami a besorozott gyerekkatonák összlétszámának közel 25\%-át jelentette. Veszteségeik szintén kiugróan magasak voltak a vizsgált periódusban: 171 fiú életét veszítette, 103-an pedig súlyos és maradandó egészségkárosodást szenvedtek a harcokban, ellenőrzőpontok működtetése vagy logisztikai feladatok ellátása közben. ${ }^{15} \mathrm{~A}$ statisztikát tovább árnyalja egy jemeni civil szervezet felmérése, amely szerint a polgárháború bizonyos szakaszában az akkor elesett gyerekkatonák $50 \%$-a 15 évesnél fiatalabb volt. ${ }^{16}$

A halottak számának mintegy kétszeresét, azaz 340 fiút fosztottak meg szabadságától a szemben álló felek három hónaptól három évig terjedő időtartamra az ellenséggel való együttmüködés gyanúja miatt. A bebörtönzött fiatalok kapcsán kimutatható volt, hogy 45\%-ukat (153 fö) a Népi Ellenállás eröi, 21\%-ukat (72 fö) a húszik, ${ }^{17} 16 \%$-ukat (54 fö) pedig a jemeni fegyveres erők fogták el. ${ }^{18} \mathrm{~A}$ tendenciákat elemezve megállapítható volt továbbá, hogy az elfogott fiúk számában a Szaúd-Arábia vezette koalíciós erők beavatkozása

13 Mohamed Aszkar jemeni emberi jogi miniszter az ENSZ adatainál jóval többre, mintegy 30 ezer főre becsülte a húszik által a polgárháború kirobbanásától 2019 közepéig besorozott gyermekek számát. Az adatok mintegy 15-szörös különbségénél figyelembe kell venni, hogy az ENSZ statisztikái egyéni beszámolókon alapulnak, az érintett családok közül sok a szégyentől és a megtorlástól félve nem mer nyilatkozni, a hivatalos jemeni adatbázisokhoz pedig rendkívül korlátozott hozzáféréssel rendelkeznek. A valós számok ezáltal magasabbak lehetnek a beszámolókban feltüntetetteknél. A jemeni kormányszervek tájékoztatása ugyanekkor becsléseken alapul, mivel nekik sincsenek pontos információik ellenfeleik valós erejéről. Emellett a gyerekek tízezres nagyságrendű besorozásának hangoztatása propagandafogásnak is tekinthető, amivel tovább kívánják rontani ellenfeleik kedvezőtlen külföldi megítélését, el kívánják érni azok nemzetközi elítélését, valamint kimondatlanul legitimálni akarják a koalíciós erők beavatkozását az ellenük vívott harcban. Ezt bizonyítja Moammer al-Erjani információs miniszter alig eltúlzott nyilatkozata is, ami szerint a húszik körülbelül 50 ezer gyermeket - köztük mintegy 5000 lányt - toboroztak alig három hónap leforgása alatt 2019 júniusáig. Mindezek okán a valós számok valahol az arany középúton helyezkedhetnek. Ezt igazolja egy, a neve elhallgatását kérő magas rangú húszi katonai vezető nyilatkozata is, aki 18 ezer főben jelölte meg a 2018 végéig besorozott gyerekek számát. Lásd NBC News: Children as young as 10 fight, kill and die in Yemen's war. [online], 2018. 12. 19. Forrás: nbcnews.com [2020. 10. 04.]; Middle East Monitor: Yemen's Houthis recruit 30,000 child soldiers: Minister. [online], 2019. 07. 11. Forrás: middleeastmonitor.com [2020. 10. 03.]; Anna Varfolomeeva: Houthis recruit 50,000 Yemen child soldiers in 3 months, minister says. [online], 2019. 06. 20. Forrás: thedefensepost.com [2020. 10. 04.]

14 Az ENSZ kimutatásai szerint a húszik mellett a Népi Ellenállás 317 főt, a kormányerők 274 főt, a Biztonsági Övezet Erői 189 főt, az al-Káida az Arab-félszigeten 148 főt, a szalafiták 65 föt, az Anszár as-Saría 30 főt, a Sabvani Elit Erők 26 főt, a Jemeni Iszláh Párt 17 föt, a Hirak Déli Mozgalom 13 föt, a Hadrami Elit Erők 6 föt, a törzsi csoportok 4 föt, ismeretlen csoportok 3 föt, az ISIS helyi ága 1 föt, a Déli Átmeneti Tanácshoz kötődő csapatok pedig 1 föt soroztak be. Lásd UN General Assembly Security Council (2019) i. m.

15 UN General Assembly Security Council (2019) i. m.

16 Fatima Abo Alasrar: Yemen's pied piper: A child soldier tragedy. [online], 2020. 02. 24. Forrás: insidearabia.com [2020. 10. 10.]

17 A húszik 64 fogoly gyerekkatonát engedtek el 2020-ban. Szabadságuk teljes visszanyerése elött azonban a fiatalokat egy két hónapos rehabilitációs kurzusnak vetették alá a síita szociális minisztérium felügyelete alatt, ami egyértelműen vallási-ideológiai-politikai meggyőződésük befolyásolására irányult. A gyakorlat nem egyedülálló, mivel szintén egy három hónapos rehabilitációs programon vett részt az a 15 szaúdi határ mentén elfogott húszi gyerekmilicista, akiket még 2018-ban adtak át az arab koalíciós erők a jemeni kormány képviselőinek. Lásd News 18: Yemen’s Houthi Rebels Vow to Treat and Release 64 Captive Child Soldiers. [online], 2020. 01. 27. Forrás: news18.com [2020. 10. 04.]; Al Arabiya: Coalition returns 15 Houthi child soldiers to Yemen govt after rehabilitation. [online], 2018. 11. 27. Forrás: english.alarabiya. net [2020. 10.04.]

18 UN General Assembly Security Council (2019) i. m. 
után és a polgárháború intenzitásának fokozódását követően radikális kiugrás (21-szeres növekedés!) következett be 2015-ben. Habár számuk jelentősen csökkent az elkövetkezö években, arányuk még így is jelentős volt a polgárháború eleji állapotokhoz képest. ${ }^{19}$

Az elszenvedett fizikai ártalmak mellett hozzávetőleg sem lehet megbecsülni a mentálisan sérültek számát. Beszámolók szerint az ütközetet megjárt fiatalok között általánosak voltak a poszttraumás stressz szindróma tünetei. Sokukon szorongás, pánikroham, dekoncentráltság, fásultság és kiábrándultság uralkodott el, ami gyakran az erőszakra való hajlam felerősödésével járt együtt. Súlyosabb kórképet mutattak ki azoknál, akiket saját parancsnokaik éheztettek, vertek, bajtársaik meggyilkolására kényszerítettek vagy szexuálisan bántalmaztak. ${ }^{20}$ Megfelelö kezelésükre jelenleg is alig van mód és lehetőség Jemenben. A fegyveres erőktől dezertált gyermekek többsége emellett a megtorlás veszélye miatt nem térhet vissza eredeti lakóhelyére, ezért kénytelen a belső menekültek számára létrehozott valamelyik szükségtáborban élni, ahol a szűkös és kritikus feltételek mellett rendszeres az éhezés és a járványok terjedése. Az átélt megrázkódtatás feldolgozását tovább nehezíti mindezeken túl, hogy a jemeni társadalom konzervatív közösségei még napjainkban is kirekesztik a mentális betegeket, akiknek emiatt titkolni kell panaszaikat, a tüneteket pedig el kell fojtani magukban.

\section{A fiatalok csatlakozásának okai}

A gyermekek célirányos megszólítása és harctéri alkalmazása már a jelenlegi konfliktus kirobbanása előtt is mindennaposnak számított. Beszámolók tanúsága szerint már az 1994-es polgárháborúban a szemben álló felek gyakran erőszakkal soroztak be gyerekeket, többségüket a fennhatóságuk alatt élt törzsek tagjai közül. Tevékenységüket megkönnyítette, hogy ezek a fiatalok már gyermekkorukban elsajátították a fegyverhasználatot. Jemen egyes régióiban és bizonyos törzsei által követett sajátos tradícióknak köszönhetően ugyanis a fiúgyermekek bizonyos életkor - általában 14-15 év - betöltését követően automatikusan fegyvert viseltek, ami a felnőttkor elérését jelképezte. Státuszszimbólumuk birtokában kiemelt megbecsülést élveztek ezekben a közösségekben, mint a törzsi, etnikai és vallási identitás védelmezői. ${ }^{21}$ Gyakran ők őrizték emiatt a katföldeket, ${ }^{22}$ valamint aktívan részt vettek a rivális törzsekkel folytatott fegyveres összetüzésekben. ${ }^{23}$

19 2013-ban és 2014-ben 9-9 esetet jegyeztek fel, 2015-ben 188-at, 2016-ban 15-öt, 2017-ben 23-at, 2018-ban pedig 96-ot. Lásd UN General Assembly Security Council (2019) i. m.

20 Hollie McKay: Yemen's child soldiers face long road after sexual, physical abuse. [online], 2018. 07. 24. Forrás: foxnews. com [2020. 10. 04.]

${ }^{21}$ Harceszközeiket még az iskolába is magukkal vitték tanszereik mellett. Ennek következményeként egy alkalommal tíz személy meghalt, három pedig megsérült, amikor két különböző törzsből származó diák vitája erőszakba torkolt. Lásd Child Soldiers International: Child Soldiers Global Report 2001 - Yemen. [online], 2001. Forrás: refworld.org [2020. 10. 10.]

22 A kat egy, a jemeni felnőtt férfiak között széles körben elterjedt bódító narkotikumfajta.

23 Az ország elmaradottabb, rurális területein napjainkban is meghatározó az a törzsi kultúra, amely a család és az általuk lakott/birtokolt föld védelmére teljesen elfogadhatónak tartja a gyermekek harcba küldését. 
A fenti gyakorlatot gyakran alkalmazták a Húszi törzsből kinőtt síita mozgalom milíciái is. ${ }^{24} \mathrm{Az}$ Irán által támogatott félkatonai alakulatok ideális önkéntesnek tartották a fiatalokat naivitásuk, befolyásolhatóságuk, eltökéltségük, gyorsaságuk és vak engedelmeskedésük, valamint a felnőtteknél jóval csekélyebb anyagi igényeik és élelmiszer-szükségleteik miatt. Rendszeresen bevetették őket a jemeni kormányzattal vívott hat háborújuk alkalmával 2004 és 2010 között, illetve a 2011-es zavargások alatt, majd pedig a húszik befolyásának kiterjesztése idején kulcsszerepet játszottak a városok fegyveres megszállásában a harcosok kalauzaként vagy informátoraként. ${ }^{25}$

A negatív tendencia a koalíciós erők 2015 márciusában megindított hadműveleteit követően újabb lendületet vett és a polgárháborús felek növekvő számban soroztak be gyermekeket a fennhatóságuk alatt álló különféle oktatási intézményekben, árvaházakban, mecsetekben, forgalmas piacokon, a különféle szabadidős terekben (például futballpályáknál), menekülttáborokban és a sürün lakott régiók tradicionális mikroközösségeiben. A csatlakozás az esetek túlnyomó részében önkéntes alapon történt, főleg az iskoláskorúak körében. ${ }^{26} \mathrm{~A}$ polgárháború elhúzódása és az azzal járó pusztítás, a gazdasági élet széthullása, a munkaerőpiac beszükülése a magán- és közszférában, az állami kifizetések felfüggesztése miatt a közalkalmazottak megélhetésének veszélybe kerülése sok fiatalban megkérdőjelezte a tanulás és a végzettségszerzés értelmét. A fatalista szemléletmódot megerősítette körükben, hogy sokan a milíciákhoz vagy a biztonsági erőkhöz való csatlakozást tartották a legcélravezetőbbnek arra, hogy rövid idő alatt anyagi bevételhez jussanak. A húszik ugyanis havonta körülbelül 20-30 ezer jemeni riált - aktuális árfolyamon számolva 24-36 ezer forintnak megfelelö összeget - fizettek a gyerekkatonáiknak, amit évente kétszer bónusztámogatással egészítettek ki. ${ }^{27} \mathrm{~A}$ kormánypárti erők ennek az összegnek a dupláját, mintegy 60 ezer riált - 72 ezer forintnak megfelelő összeget - tudtak felajánlani a szaúdi és az emirátusbeli támogatásoknak köszönhetően.$^{28} \mathrm{Az}$ önkéntes csatlakozás emiatt sokak számára kizárólagos esélyt jelent a túlélésre, mivel az így kapott kereset birtokában tudnak csak kielégítően gondoskodni önmagukról és családjukról..$^{29}$

24 A síita törzsek azonos vallási és ideológiai meggyőződésük mellett egyfajta önvédelmi reflexió miatt vonultatták be gyerekeiket a húszik oldalán. Álláspontjuk a koalíciós támadások 2015. márciusi megindítását követően megerősítést nyert, ami tetten érhető volt többek között a fiatal újoncok létszámának kiugró növekedésében.

25 Az ENSZ 2011-ben 20\%-ra becsülte a gyerekek arányát a húszi harcosok között, 15\%-ra pedig a kormányerőkhöz kötődő törzsi milíciákon belül. Lásd Adel Yahya: Conflict generating more child soldiers. [online], 2011. 07. 20. Forrás: thenewhumanitarian.org [2020. 10. 10.]

26 Az ENSZ jelentése szerint a húszik 20 iskolában toboroztak és képeztek ki gyermekeket 2018-ban. Az említett intézmények közül négyben kimondottan lányokat próbáltak csatlakozásra bírni. Lásd UN General Assembly Security Council (2019) i. m.

27 Összevetésként érdemes figyelembe venni azt is, hogy 30 ezer jemeni riál vásárlóértéke jelenleg megfelel 117 fél kilós kenyér, vagy 47 kiló rizs, vagy 66 liter tej, vagy 32 kiló alma, vagy közel 16,2 kiló csirkehús, vagy 6,5 kiló marhahús, vagy 37,5 doboz Marlboro cigaretta árának. Emellett az összeg 90\%-a egyenértékű egy külvárosi, egyszobás apartman havi bérleti díjával. Lásd Numbeo: Cost of living in Yemen. [online], Forrás: numbeo.com [2020. 10. 10.]

28 Alasrar (2020) i. m.; Sana Uqba: Yemen in focus: Saudi-coalition recruits child soldiers for border protection. [online], 2019. 04. 05. Forrás: english.alaraby.co.uk [2020. 10.10.]

29 Az immáron hat éve folyamatosan zajló polgárháború egyik eredményeként napjainkban 24 millió jemeni állampolgár, azaz a lakosság mintegy 80\%-a szorul humanitárius segélyre vagy védelemre. Közülük 10 millió fó súlyos élelmiszerhiánnyal küzd. Lásd: European Civil Protection and Humanitarian Aid Operations: Yemen. [online], Forrás: ec.europa.eu [2020. 10.03.] 
Az individualista törekvések halmozottan megmutatkoztak azoknak a fiúknak az esetében, akik valamilyen okból kifolyólag (például az iskola lebombázása vagy a magas tandíjak miatt) az oktatási rendszeren kívül rekedtek. ${ }^{30}$ Stabil jövőkép hiányában az ő szempontjukból az arab koalíciós erőkhöz vagy a jemeni fegyveres milíciákhoz való jelentkezés az egyetlen érvényesülési alternatívát jelentette.

Néhány fiatal számára a harcok a mielőbbi haszonszerzés mellett kizárólagos lehetőséget nyújtottak az előnyös házasság megkötésére is. Hagyományosan sok helyen még ma is meg kell váltania a vőlegénynek a menyasszonyt családjától, aminek az összege nagyban függ többek között a kiszemelt lány életkorától, társadalmi státuszától és családi állapotától. Ennek megfelelően egy átlagos férfi mindennapi keresete jobb esetben csak arra elegendő, hogy elvált vagy özvegy nőt vegyen feleségül, rosszabb esetben pedig egyáltalán nem teszi lehetővé a családalapítást. A házasságkötés életkora emiatt kitolódott a férfiak között. Azok ellenben, akik a szaúdiak és az emirátusok által finanszírozott csapatok valamelyikéhez csatlakoztak, rendszeres havi járandóságukból sokkal hamarabb és könnyebben tudtak az elvárásaiknak jobban megfelelő hajadont feleségül venni, mint a velük egykorú sorstársaik.

Az anyagi szempontok mellett a tradíciók is meghatározó mobilizációs tényezőnek bizonyultak a fiatalok számára. Főleg a húszi ellenőrzés alatt álló területeken számos gyermeket motivált, hogy bosszút álljon törzsének elesett férfitagjaiért. Az egyedi önkéntes részvétel mellett ugyanakkor megfigyelhető volt az is, hogy a közösség férfitagjai - életkortól függetlenül - kollektívan - azaz apák és fiúk együtt - vonultak hadba, amikor a törzsfők arra adtak utasítást.

A fiúk számára mérvadó szempontnak számított még a lehetőség a felnőttséget és a férfiasságot szimbolizáló lőfegyver szabad birtoklására, a frontról hazatért rokonok és ismerősök beszámolói, illetve a szülők ideológiai elkötelezettsége valamelyik oldal mellett. A fiatalok harci kedvének feltüzelésére a húszik propagandatevékenységüket kiterjesztették az iskolákra és a nyári táborokra, ahol rendszeresen tartanak fegyverbemutatókat és hazafias beszédeket a tanulóknak. ${ }^{31}$

A lehetséges önkéntesek mobilizálására a húszik helyi központokat is létrehoztak az ifjak vallási meggyőződésének elmélyítésére, ahol a megjelenteket a közös imádságok során példabeszédekkel bátorították az ország fegyveres védelmére. Emellett irányításuk alá vonták a Korán-iskolákat is, ahol vallási bevezető tanulmányok ürügyén az arab koalíciós erők elleni harcra is felkészítették mentálisan a résztvevőket. ${ }^{32}$

A hatékonyabb toborzás érdekében a húszik hat tartományban 34 lányt is soraikba fogadtak 2020 júniusáig. A 13-17 éves lányok fő feladata a húszi háborús erőfeszítések támogatása és paramilitáris tevékenység folytatása volt. Ennek értelmében kémkedtek,

30 Csak 2018 végéig mintegy 3,4 millió főre becsülték az oktatási rendszerből kikerült iskoláskorúak számát. Lásd War Child: Yemen. [online], Forrás: warchild.org.uk [2020. 10. 10.]

31 A húsziktól függetlenül a velük szimpatizáló Szaada környékbeli törzsek is rendszeresen rendeztek különleges toborzó napokat az iskolákba a síita milíciák támogatására és a harci szellem felélesztésére. Lásd Alasrar (2020) i. m.; Human Rights Council: Situation of human rights in Yemen, including violations and abuses since September 2014. A/HRC/45/ CRP.7. [online], 2020. 09. 20. 68-69. Forrás: ohchr.org [2020. 10. 10.]

32 Amnesty International: Yemen: Huthi forces recruiting child soldiers for front-line combat. [online], 2017. 02. 28. Forrás: amnesty.org [2020.10.10.] 
őrséget álltak, elsősegélyt nyújtottak a frontvonalon a sebesülteknek, további lányönkénteseket szerveztek be, az anyákat és a nővéreket pedig férfi hozzátartozóik harcba küldésére, valamint a fegyveresek anyagi támogatására bíztatták. Toborzótevékenységüket főleg a húszikhoz kötődő családokban, valamint a gazdaságilag és társadalmilag marginalizálódott személyek között fejtették ki. Rendszeresen felbukkantak emellett a börtönökben, a köztereken és a különféle oktatási intézményekben is. ${ }^{33} \mathrm{~A}$ jelentések alapján habár fegyveres kiképzésben részesültek, ennek ellenére összecsapásokban nem vettek részt.

Az országban külön ügynökhálózat is létrejött az önkéntesek verbuválására, ami elsősorban a Szaúd-Arábiának és a vele szövetséges jemeni erőknek gyüjtötte a jelentkezőket. Mivel tevékenységüket fejpénzzel (1000 szaúdi riál/fó, azaz aktuális árfolyamon mintegy 80 ezer forint személyenként) díjazták és a folyamatos emberhiány miatt gyakorlatilag nem volt kritérium megszabva az újoncok felvételénél. ${ }^{34}$ A lehető legtöbb embert próbálták emiatt beszervezni, függetlenül azok korától és képességeitől. Tevékenységük hatására nemegyszer egyfajta dominóhatás ment végbe egyes településeken, amikor az első jelentkező példáját gyors egymásutánban követték annak rokonai, barátai, majd pedig csatlakoztak utóbbiak hozzátartozói és ismerősei is. Müködésük nemegyszer olyan eredményesnek bizonyult, hogy az ország bizonyos régióiban a fiatalok akár $80 \%$-a is önként vállalta a fegyveres harcot. ${ }^{35} \mathrm{~A}$ kellő számú önkéntes összegyüjtését követően a toborzók általában embercsempészeknek adták át a fiúkat, majd leszállították őket az egyik határ menti katonai táborba. ${ }^{36}$

Ahol azonban az újoncok száma nem felelt meg az elvárásoknak, ott a toborzók és a közvetítők gyakran vesztegetéssel vagy nyomásgyakorlással igyekeztek ellehetetleníteni minden helyi kezdeményezést - például sport- vagy kulturális egyesületek működése -, ami visszatartó erőt képezhetett volna a fiatalok számára. Az unatkozó, sokszor csoportokba verődött fiúkkal azután már könnyebb volt személyes kapcsolatot kialakítani és meggyözéssel vagy hamis ígéretekkel csatlakozásra bírni őket. ${ }^{37}$

Ha azonban a rábeszélés és a megtévesztés sem tudta a kívánt hatást kiváltani, akkor bizonyos helyzetben kényszer alkalmazására is sor került. A húszik rendszeresen végeztek adatgyüjtést az anyakönyvi hivatal és az egyéb állami hivatalok adatbázisaiban, amelyek alapján listákat állítottak össze az általuk katonai szolgálatra alkalmasnak tartott fiúkról. Utóbbiak birtokában azután célirányosan csaptak le az iskolákra vagy a legkiszolgáltatot-

33 Két olyan incidenst is rögzítettek a lányok toborzótevékenységével kapcsolatban, amikor az önkéntesek botokkal és lőfegyverekkel a kezükben hatoltak be egy iskolába, ahol az ott-tartózkodó lányokat a harc támogatására bátorították, valamint húszi szlogenek ismétlésére kényszerítették őket. Lásd Human Rights Council (2020) i. m. 71.; UN General Assembly Security Council (2019) i. m.; EG24 News: New Al-Houthi after „Al-Zainabiyat” ... „Fatimiya” to spread ideas. [online], 2020. 05. 25. Forrás: eg24.news [2020. 10.11.]

34 Human Rights Council (2020) i. m. 67.

35 Fawziah Al-Ammar - Hannah Patchett - Shams Shamsan: A gendered crisis: Understanding the experiences of Yemen's war. Sana'a, Sana'a Center for Strategic Studies, 2019. 55.

36 Beszámolók alapján a jemeni fiúkat döntően vagy az al-Buka, vagy a Kitaf melletti katonai kiképzőtáborba vitték. A harci övezetbe való belépés előtt a fiataloknak diákigazolványukkal - vagy annak hiányában egy, az embercsempészek által átadott nem hivatalos katonai személyigazolvánnyal - kellett magukat igazolniuk. Lásd Al Jazeera: Exclusive: Yemeni child soldiers recruited by Saudi-UAE coalition. [online], 2019. 04. 01. Forrás: aljazeera.com [2020. 10. 11.]

37 Sok, a szaúdi erők támogatására toborzott fiút azzal vettek rá a csatlakozásra, hogy belépésüket követően 3000 szaúdi riál fizetségért konyhai szolgálatra fogják őket alkalmazni a szomszédos állam területén állomásozó egységek ellátásra. Lásd Al Jazeera (2019) i. m. 
tabb családok szálláshelyeire, ahol elrabolták az ott talált fiatalokat. Egy 12 éves jemeni fiú elmondta azt is, hogy a húszi milicisták új iskolatáskák osztogatásának ígéretével vitték el őt és tíz további osztálytársát. ${ }^{38}$ Helyszíni beszámolók alapján gyakran előfordult az is a fővárosban, hogy a toborzók házakat kerestek fel, ahol a szülőktől vagy a fiúk, vagy pedig egy jelentősebb összegű anyagi támogatás átadását követelték háborús erőfeszítéseik támogatására. Ezzel kapcsolatban több szanaai lakos egyhangúan arról nyilatkozott, hogy a húszik biztonsági övezetekre osztották fel a fövárost, amelyek élére felügyelőket neveztek ki. Utóbbiak feladata volt, hogy házról házra járva naprakész információval rendelkezzenek az illetékességük alá tartozó területen élő családok férfitagjairól, valamint ezek alapján teljesítsék a központilag megállapított sorozási kvótákat. ${ }^{39} \mathrm{~A}$ húszik nyomásgyakorlásába beletartozott a zsarolás is, amikor az általuk fogságban tartottak szabadon engedését azok fiúrokonainak csatlakozásától tették függővé. ${ }^{40}$ Legvégül több alkalommal került sor arra is, hogy a húszik kényszertoborzást végeztek az őrizetükben lévő fiatal fiúk között, akiket őreik megfélemlítéssel, rossz bánásmóddal vagy kínzással kényszerítettek csatlakozásra. ${ }^{41}$

A sürübben lakott településeken a hozzátartozók végletekig eltérően reagáltak fiaik vagy fiúrokonaik besorozására. A trendek alapján megállapítható, hogy a reakciók jellege és intenzitása alapvetően az egyes családok dinamikájától függött, amire a földrajzi és demográfiai különbségek csekély hatással voltak. Ennek megfelelően egyes családok - döntően anyagi vagy morális megfontolásból - kimondottan bátorították fiúikat a harcra, míg mások megpróbálták megakadályozni belépésüket a fegyveresek közé. Ezáltal bizonyos esetben a szülők egyike vagy mindegyike presszionálta - esetleg szélsőséges esetben akár kimondottan kényszerítette is - gyermekét a harcoló erőkhöz való csatlakozásra. Máskor viszont több apa is nyilvánosan kitagadta fiait Szanaa külvárosában, akik a szülői akarattal dacolva a frontra mentek harcolni, ahonnan azután nem voltak hajlandóak visszatérni otthonaikba. ${ }^{42} \mathrm{Az}$ esetleges nézetkülönbségek mellett a családon belüli feszültségeket tovább élezhette, ha a fiúk a szülöi tiltás miatt eltitkolták csatlakozási szándékukat, amire emiatt rokonaik tudta vagy engedélye nélkül került sor. Mukallában például az egyik közösség vezetője elmondta, hogy egy család csak akkor szerzett tudomást gyermekük besorozásáról, amikor annak halálhíréről értesítették őket. A fiú távozásakor csak annyit mondott szüleinek, hogy elmegy munkát keresni megélhetésük támogatására. ${ }^{43}$

\section{A húszi gyerekkatonák felkészítése a harcra}

A húszik által besorozott újoncok az első mintegy négyhetes periódus alatt általában kizárólag vallásoktatásban részesültek valamelyik „kulturális központban”. Kiképzőik ezalatt tudatosították bennük, hogy a zsidók, a keresztények és a nyugati befolyás alá került arab országok ellen vívott szent háborúban vesznek részt, ezért haláluk esetén a mennybe

38 Maggie Michael: These child soldiers are 'firewood' for the war in Yemen. [online], 2018. 12. 19. Forrás: globalnews.ca [2020. 10. 11.]

39 Michael (2018) i. m.

$40 \quad$ NBC News (2018) i. m.

41 Human Rights Council (2020) i. m. 69.

42 Al-Ammar - Patchett - Shamsan (2019) i. m. 54.

43 Al-Ammar - Patchett - Shamsan (2019) i. m. 54. 
kerülnek. A síita tanok hangsúlyozása és a húszi mozgalom alapítója, a 2004-ben meggyilkolt Husszein Badreddin al-Húszi nézeteinek népszerüsítése mellett kiemelt szerepe volt a szunnita irányzattal kapcsolatos különbségek kiemelésének és átpolitizálásának is. Az ellenségkép dehumanizálására a húszik vérszomjas szalafitának mutatták be a jemeni kormánycsapatokat és az arab koalíciós erők tagjait, az ISIS kapcsán pedig visszatérően hivatkoztak a terrorszervezet által elkövetett tömeges és brutális kivégzésekre. A fanatizált újoncok többségében emiatt az a meggyőződés alakult ki, hogy nem számíthatnak kegyelemre, ezért a legreménytelenebb helyzetben is halálukig harcoltak a fogságba esés elkerülésére. ${ }^{44}$

A fiatalok eltökéltségének növelésére a húszik a kat növény fogyasztására is bátorították az önkénteseket, hogy ezáltal is növeljék kiszolgáltatottságukat, valamint tompítsák félelmeiket és kétségeiket. Az oktatást azok a harci költemények és indulók, illetve törzsi énekek tették teljessé, amelyeket a fiatalok a szünetekben hallgattak..$^{45}$ Állhatatosságuk és kiszolgáltatottságuk növelésére teljesen elszigetelték őket hozzátartozóiktól a kiképzés teljes időtartamára, amire gyakran egy olyan tartományban került sor, ahol semmilyen kötődéssel sem rendelkeztek.

Az elméleti tréninget követően az újoncokat a hegyekbe vezényelték az egyik ottani kiképzőtáborba, ahol megtanultak bánni a lőfegyverrel és a robbanóanyaggal, valamint fedezéket keresni maguknak ellenséges légitámadás esetén. A felkészítés végén mindannyian egy sorszámmal ellátott karkötőt kaptak, ami hivatalosan kabalaként szolgált. A karékszer azonban inkább egyfajta „dögcédula” volt, amely segített beazonosítani és visszajuttatni családjukhoz az elesett fiatalok holttestét. A húszik kritikusai emiatt cinikusan csak a "gyerekek belépője a mennybe" elnevezéssel emlegették. ${ }^{46}$

Ellenfeleikhez hasonlóan a húszik szerteágazóan alkalmazták az újoncokat kiképzésüket követően. Felhasználták őket kémkedésre, járőrözésre, ellenőrzőpontok müködtetésére, személyvédelemre, katonai objektumok és kormányzati épületek őrzésére, utánpótlás szállítására, étel elkészítésére, sérültek ellátására, halottak összegyüjtésére és eltemetésére vagy a szálláskörzet tisztán tartására. Mindezek mellett bevetették őket a szaúdi határ mentén vagy éppen az ország nyugati partvidéken kirobbant fegyveres összecsapásokban sorkatonaként, orvlövészként, felderítőként, futárként vagy tüzérként. A 11-13 éves fiúk sorkatonai alkalmazásuk mellett rendszeresen vezettek egyedül löszerrel, tüzérségi lövedékekkel, rakétákkal és robbanóanyaggal megrakott kisteherautókat a fronton szolgáló csapatok készleteinek kiegészítésére. Nem számított kivételesnek az sem, hogy 13 éves fiúk hároméves katonai szolgálatuk vége felé már egyedül és professzionálisan müködtettek rakéta-sorozatvetőket. ${ }^{47}$ Öngyilkos merényletek végrehajtására ugyanakkor csak a terror-

44 Alasrar (2020) i. m.

45 A „Menj el a zsidókhoz és a szaúdiakhoz, és vidd el hozzájuk a hírt, hogy pokolra kerülnek a zsarnokok”, a „Szaadai kattal a szádban és harci indulóval a füledben bármire képes vagy" és az ezekhez hasonló szövegü, szélsőséges üzenetet megfogalmazó dalok népszerüek voltak a fiatal önkéntesek között. Lásd Alasrar (2020) i. m.

46 Michael (2018) i. m.

47 Sarah El-Sirgany: Firing guns, finding bodies: Life for Yemen's child soldiers. [online], 2018. 02. 03. Forrás: edition.cnn. com [2020. 10.11.] 
szervezetek, valamint az azokhoz kötődő pártok és oktatási intézmények alkalmaztak - különösen Áden városában - tanulókat. ${ }^{48}$

Az ütközetbe vezényelt, agymosott fiatalok közül sokan már az első harcérintkezések alkalmával életüket veszítették vagy megnyomorodtak a felszínes kiképzés miatt. Beszámolók alapján voltak közöttük olyanok is, akik az összecsapásokban megpróbáltak visszavonulni, ezért bajtársaik vagy feletteseik végeztek velük. A legtöbb áldozatot ugyanakkor a légicsapások szedték közülük, amelyek ellen egyesek szükségfedezékek kialakításával, mások pedig mindössze talizmánok viselésével próbáltak védekezni.

\section{Az elszenvedett veszteségek átmisztifikálása}

A húszik több millió jemeni riált fordítottak eddig arra, hogy az elszenvedett veszteségekből is előnyt tudjanak kovácsolni maguknak. Propagandájukkal egyfajta sajátos mártírkultuszt teremtettek, amikor a közvélemény elött hősöknek állították be az elesett fiúkat, akiket saját halottjaiknak tekintettek. A temetéseket emiatt elöre megkonstruált forgatókönyv szerint, az eseményeket gyakran folyamatosan rögzítve bonyolították le. A zöld vászonnal borított fakoporsóba tett holttesteket színpadiasan egy kimondottan a mártíroknak létrehozott temetőben, valamelyik fehér virágokkal és zöld füvel borított sírboltban helyezték el látványosan. Az elhunyt szülei ugyanekkor élelmiszeradagokat vagy csekély összegü (aktuális árfolyamon átváltva 24 500-36 500 forintnak megfelelö) anyagi támogatást és egy fegyvert kapnak, ha fiuk korábban önkéntesen lépett be a húszik közé. A gyászszertartásról készített felvételeket később a húszik rendszeresen közzétették különböző médiafórumaikon, míg a mártírok emlékplakátjait köztereken ragasztották ki, hogy a halott fiúk emlékét felhasználva újabb önkénteseket nyerjenek meg ügyüknek. A húszik emellett kollektív megemlékezést is tartattak az elhunytakról a minden év februárjában megtartott mártírok hetén. Ezen időszak alatt az iskolákban a harcban elesett fiúk fényképeit a tanárok kötelesek voltak kitenni a tantermek üresen maradt ülöhelyeire. ${ }^{49}$ A síita lázadók által müködtetett Oktatási Minisztérium még az iskolai tantervekbe is beépítette a mártíromság kötelező oktatását 2020 elején. Az északi Szaada tartomány középiskoláiban ennek értelmében már napi szinten kötelesek nézni Abd al-Malik Badreddin al-Húszinak, a lázadók vezérének napi videóüzeneteit, amiben a mártíromság jutalmairól és a frontvonalon vívott küzdelemről tart előadásokat a diákoknak. ${ }^{50}$

A mesterkélt mítoszképzés képesnek bizonyult felszítani a hazafias érzelmeket és a boszszúvágyat a húszikkal szimpatizáló közösségekben, miközben a fiatalok felé azt kommunikálta, hogy egyenrangúnak tekintik őket a felnőttekkel. ${ }^{51}$ A halott gyermekek fényképeinek közzététele a közösségi médiában ugyanakkor rendkívüli felháborodást váltott ki mind belföldön, mind nemzetközi szinten. Abd al-Malik Badreddin al-Húszi emiatt 2018. január

48 International Organization for Least Developed Countries: Child Recruitment in Yemen: Challenges facing the United Nation Mechanisms. Geneva, 2019. 15-16. [online], Forrás: ioldc.org [2020. 10. 11.]

49 NBC News (2018) i. m.

50 Sana Uqba: Yemen in Focus: Houthis introduce martyrdom lectures into Saada school syllabus. [online], 2020.02. 26. Forrás: english.alaraby.co.uk [2020. 10. 17.]

51 Saeed Al-Batati: Missing boy's death exposes Houthi child recruitment. [online], 2020. 08. 15. Forrás: arabnews.com [2020. 10. 18.] 
5-án rendeletben tiltotta meg a 15 év alatti elesett harcosok képeinek nyilvánosságra hozatalát, hogy elkerülje a húszik kedvezőtlen bel- és külföldi megítélésének további romlását. ${ }^{52}$

\section{Külföldi gyerekzsoldosok Jemenben}

Hivatalosan meg nem erősített információk alapján Szaúd-Arábia Líbiából és Szudánból is toborzott gyerekeket a Jemennel közös határainak védelmére. ${ }^{53} \mathrm{~A}$ döntésben a sivatagi királyságot a védelem megerősítése és a saját veszteségek minimalizálása mellett egyfajta költséghatékonysági szempontok is motiválták. A szaúdi Honvédelmi Minisztérium honlapján közzétett adatok szerint ugyanis a jemeni háborúban elhunyt szaúdi katonák családjai a haláleset bekövetkeztét követően azonnal 100 ezer szaúdi riál (26 662 dollár) kárpótlást kapnak, majd később ennek az összegnek a tízszeresét utalják át részükre, azaz mindent összevetve közel 300 ezer dollárt fizetnek ki minden egyes elesett katonáért. Ugyanekkor a szaúdi zsoldban elesett jemeni önkéntesek családjának kifizetett jóvátétel együttesen sem haladja meg a 4000 dollárt. $^{54}$

A nagyságrendekkel csekélyebb szaúdi anyagi támogatás ugyanakkor vonzó hatással volt a szudániakra, akik szinte kivétel nélkül a háború sújtotta Dárfúr régióból származtak. A rotációs rendszerben bevetett zsoldosok az arab koalíciós erők részeként 2-4 hetes formális felkészítésüket követően önálló, 500-750 fős szárazföldi egységekbe tagolva az északi front kulcsfontosságú szakaszain a szövetséges jemeni milíciák szárnyfedezetét látták el 2015-től. A képet tovább árnyalják a hazatért zsoldosok beszámolói, amelyek szerint a koalíciós csapatok gyakorlatilag a szaúdi szárazföldi erők kiváltására használták őket. Ennek megfelelően soha nem harcoltak az oldalukon az ütközetekben, szaúdi és emirátusbeli feletteseik pedig rádión vagy telefonon adták ki nekik a parancsokat a frontvonaltól biztonságos távolságban. ${ }^{55}$

A gyerekkatonák, akiknek az arányát eltérő becslések 20-40\% közé taksálták a zsoldosok között, kiemelt fizetést kaptak az önkéntes fegyveres misszióért. A szaúdi tulajdonban lévő Szudáni Fejszál Iszlám Bank havonta legkevesebb mintegy 151 ezer forintnak megfelelő összeget helyezett letétbe számukra konvertibilis szaúdi riálban, amihez közel 60 ezer forinttal egyenértékủ bónusz is járt, ha részt vettek fegyveres összecsapásban. Ehhez járult még az egyszeri lelépési díj is a hat hónapos szolgálati idő lejártát követően, ami 3 millió forinttal volt egyenértékủ. Emiatt - a jemeni szülőkkel ellentétben - itt sok nélkülöző szudáni család kimondottan támogatta, hogy Jemenbe küldhesse 13-17 éves gyermekét harcolni, amihez szudáni illetékeseket is megvesztegettek. Összehasonlításként elmondható, hogy ugyanekkor egy több műszakban és munkahelyen egyszerre túlórázó szudáni orvos havi keresete átszámítva nem érte el a 160 ezer forintot egy olyan országban, ahol az infláció

Alasrar (2020) i. m.

Al Jazeera: Saudi Arabia recruited Darfur children to fight in Yemen: NYT. [online], 2018. 12. 29. Forrás: aljazeera.com [2020. 10. 23.]

54 Al Jazeera (2019) i. m.

55 David D. Kirkpatrick: On the front line of the Saudi war in Yemen: Child soldiers from Darfur. [online], 2018. 12. 28. Forrás: nytimes.com [2020. 10. 23.] 
mértéke évek óta folyamatosan 60-70\% között mozog, a munkanélküliség aránya meghaladja a 20\%-ot, és állandó hiány van az alapvető cikkekből. ${ }^{56}$

A szudáni katonai részvétel körülményei azonban idővel hatalmas nemzetközi felháborodást váltottak ki. Az ügy 2018 végén történt kipattanását követően az amerikai kongresszus 13 tagja írásban szólította fel Mike Pompeo külügyminisztert 2019. február 15-én azoknak a vádaknak a tisztázásra, amelyek szerint a szaúdiak amerikai fegyverekkel és egyenruhával szerelték fel a szolgálatukba fogadott gyerekkatonákat. A törvényhozás még egy állásfoglalást is előterjesztett az amerikai-szaúdi katonai együttmüködés beszüntetésére a jemeni konfliktusban, amit végül elvetettek Trump elnök április eleji vétója miatt. Pompeo külügyminiszter júniusban megakadályozta azt is, hogy Szaúd-Arábiát felvegyék arra az amerikai listára, amelyen a gyermekkatonákat toborzó országok szerepelnek. A 2008. évi Törvény a Gyerekkatonák Alkalmazásának Megelőzésére értelmében ugyanis a listán szereplő külföldi fegyveres erők nem részesülhetnek amerikai támogatásban, kiképzésben és fegyverzetben, hacsak az elnök nemzeti érdekek alapján részben vagy egészében hatályon kívül nem helyezi a szankciókat. Szaúd-Arábiának még azt is sikerült elérnie, hogy az ENSZ 2020 júniusában levegye arról a feketelistájáról, amelyen a gyermekek jogait súlyosan megsértő államok szerepelnek. ${ }^{57}$

A Szaúd-Arábiát fenyegető szankciók mellé társult a szudáni katonák növekvő népszerütlensége a jemeni lakosság körében, valamint a több éves küldetés alatt elszenvedett súlyos veszteségek. ${ }^{58}$ A 15 ezer fös szudáni katonai kontingens nagyságát emiatt hivatalosan pár száz före csökkentették le Abdalla Hamdok szudáni miniszterelnök utasítására 2020 januárjában. A szudáni zsoldosok alkalmazása azonban tovább folytatódott a háttérben, és a következő hónapok során az emirátusok által finanszírozott Fekete Pajzs Biztonsági Szolgálat utazási irodákon és egyéb közvetítőkön keresztül mintegy 3000 szudánival kötött szerződést, hogy névleg biztonsági őrként foglalkoztassák őket az Egyesült Emirátusok területén. A jelentkezőket azonban kiképzőtáborokba vitték, majd arra kényszerítették, hogy a jemeni és a líbiai frontokon harcoljanak. ${ }^{59}$

\section{Jelenlegi helyzet}

A gyermekek illegális besorozásának megszüntetésére Abd-Rabbuh Manszúr al-Hádi elnök 2020. február 18-án betiltotta a toborzótevékenységet a gyermekek körében a fegyveres

56 Independent: Child soldiers from Darfur fighting at front line of war in Yemen, returned soldiers say. [online], 2018. 12. 29. Forrás: independent.co.uk [2020. 10. 24.]

57 Congressional Research Service: Congress and the War in Yemen: Oversight and Legislation 2015-2020. [online], 2020. 06. 19. Forrás: fas.org [2020. 10. 24.]; Joshua Cossin: UN removes Saudi-led coalition in Yemen from child rights violators 'list of shame'. [online], 2020. 06. 17. Forrás: jurist.org [2020. 10. 24.]; Jonathan Landay - Matt Spetalnick: Exclusive: Overruling his experts, Pompeo keeps Saudis off U.S. child soldiers list. [online], 2019. 06. 18. Forrás: reuters.com [2020. 10. 24.]

58 A húszik szóvivője szerint a szudániak közül több mint 8000 fö halt meg, sebesült meg vagy esett fogságba 2015-2019 között. Lásd Middle East Eye: Huge Sudanese losses in Yemen highlight fighter's role in the conflict. [online], 2019. 11. 10. Forrás: middleeasteye.net [2020. 10.24.]

59 Legutóbb szeptember végén érkezett Szaúd-Arábiába közel 1500 szudáni tengeri és légi úton, hogy részt vegyen a jemeni hadmüveletekben. Lásd Ihsan Al-Faqih: UAE-based Black Shield recruits mercenaries in region. [online], 2020. 07. 18. Forrás: aa.com.tr [2020. 10. 24.]; Middle East Eye: Sudan sending hundreds of troops to Yemen via Saudi Arabia. [online], 2020. 10. 02. Forrás: middleeasteye.net [2020. 10. 24.] 
és a biztonsági erők számára. Az államfő egyúttal deklarálta azon szándékát is, hogy viszszamenő hatállyal eljárást indítanak azon katonai és polgári személyek ellen, akik korábban részt vettek gyermekek toborzásában. A döntés kiegészitésére külön szervezeti egységet hoztak létre a gyermekek védelmére a következő napon azzal a céllal, hogy a közös jemeni-ENSZ szakmai bizottsággal és a civil társadalommal együttmüködve folyamatosan figyelemmel kísérjék a gyerekek jogsértő besorozására és harctéri alkalmazására vonatkozó jelentéseket, illetve panaszokat. Az elhatározás kiterjedt a különböző katonai és biztonsági személyzet továbbképzésére is a gyermekvédelem elveiről és annak jogi kereteiről, valamint a már besorozott gyermekek átengedésére a civil szervezetek számára. Legvégül preventív intézkedésként a főiskolák, intézetek és katonai akadémiák utasítást kaptak arra, hogy tanmeneteikbe építsék be a gyermekek jogainak, valamint a toborzásuk kockázatainak oktatását. ${ }^{60}$

Szaúd-Arábia szintén számos intézkedést hozott a háborút megjárt fiatalok társadalmi visszailleszkedésének elősegítésére. Ezek egyikeként nyolc rehabilitációs központot müködtetnek Jemenben, amelyekben körülbelül 2000 gyermekkatonát kezeltek 2017-től 2019-ig. ${ }^{61}$ Ezen intézetek finanszírozása mellett a Szalmán Király Humanitárius Segítségnyújtás és Segélyezési Központ aktívan bekapcsolódott az ENSZ védnöksége alatt működő nemzetközi szakértői munkacsoport tevékenységébe a gyerekkatonák reintegrációs lehetőségeinek javítására, valamint jelentős összegekkel támogatta azokat a programokat, amelyeket a nélkülözö jemeni családok gyermekeinek megsegítésére indítottak. ${ }^{62}$

A húszik ugyanakkor tovább fokozták a toborzást a fiatalok és az iskoláskorúak között a fennhatóságuk alatt álló területeken az al-Jaúf, Nihm és ad-Dali tartományokban elszenvedett veszteségeik pótlására. Tevékenységük eredményeként több tucatnyi gyerek eltünését erősítették meg egybehangzóan helyi források öt különböző tartományban. A gyermekekröl, akik között sokan még 8 évesek sem voltak, feltételezték, hogy a húszik valamelyik kiképzőtáborába kerültek. ${ }^{63}$

\section{Utószó}

A korábbi évek tapasztalatai alapján feltételezhető, hogy a gyermekek hadi célokra való fel- és kihasználása továbbra is jelentős marad az aktuális jemeni konfliktusban. A folyamat visszafordítására mielőbb alapvető lenne a fegyveres konfliktus intenzitásának csökkentése, kiegyensúlyozott mindennapi megélhetés biztosítása a civil lakosság számára, valamint

60 Mohammed Al-Ayed: Yemen pressures Houthis to ban recruitment of child soldiers. [online], 2020. 02. 20. Forrás: english. aawsat.com [2020. 10. 25.]

61 Wethaq Foundation for Civil Orientation: Rehabilitation of child soldiers and affected by war in Yemen. [online], Forrás: wethaq.org [2020. 10. 25.]

62 Arab News: KSRELIEF takes part in Warsaw Humanitarian Exhibition. [online], 2019. 06. 11. Forrás: arabnews.com [2020. 10. 25.]; Arab News: Saudi Arabia steps up aid for Yemen child soldiers. [online], 2019. 08. 02. Forrás: arabnews. com [2020. 10.25.]

63 A jemeni kormány a csekély harcértéket képviselö gyerekek intenzív besorozása miatt azzal vádolta a húszikat, hogy a fiatalokat gyakorlatilag ágyútölteléknek használják. Muammar al-Erjani tájékoztatásügyi miniszter ezzel kapcsolatban hivatkozott a jemeni fegyveres erők által közzétett adatokra, amelyek szerint 2020. március elejére a húszik közül több mint 800-an estek el a nihmi és az al-jaúfi frontokon vívott ütközetekben. Elmondása szerint az áldozatok legtöbbje gyerekkatona volt. Lásd Asharq Al-Awsat: Houthis use Yemeni child soldiers to fuel ongoing war. [online], 2020. 03. 09. Forrás: english.aawsat.com [2020. 10.25.] 
hatékony módszerek alkalmazása az életkor megállapítására. Ennek elmaradása és a kedvezötlen tendenciák elhúzódása esetén egy olyan aluliskolázott, narkotikumfüggö és mentálisan sérült generáció nőhet fel, amelynek tagjait erőszakban szocializálták folyamatosan a Nyugat elleni gyülöletre, és az ellene vívott elkerülhetetlen harcra nevelték egy olyan országban, ahol átlagosan minden második személyre jut egy fegyver. Utóbbi kapcsán a kockázatok halmozottan fennállnak a lányok esetében, mivel a jelenlegi reintegrációs programok kizárólag a fiúkra koncentrálnak.

\section{Felhasznált irodalom}

Alasrar, Fatima Abo: Yemen's pied piper: A child soldier tragedy. [online], 2020. 02. 24. Forrás: insidearabia.com [2020. 10. 10.]

Al-Ammar, Fawziah - Hannah Patchett - Shams Shamsan: A gendered crisis: Understanding the experiences of Yemen's war. Sana'a Center for Strategic Studies, 2019.

Al-Ayed, Mohammed: Yemen pressures Houthis to ban recruitment of child soldiers. [online], 2020. 02. 20. Forrás: english.aawsat.com [2020. 10. 25.]

Al-Batati, Saeed: Missing boy's death exposes Houthi child recruitment. [online], 2020. 08. 15. Forrás: arabnews. com [2020. 10. 18.]

Al-Faqih, Ihsan: UAE-based Black Shield recruits mercenaries in region. [online], 2020. 07. 18. Forrás: aa.com. $\operatorname{tr}[2020.10 .24$.

Al Jazeera: Saudi Arabia recruited Darfur children to fight in Yemen: NYT. [online], 2018. 12. 29. Forrás: aljazeera. com [2020. 10. 23.]

Al Jazeera: Exclusive: Yemeni child soldiers recruited by Saudi-UAE coalition. [online], 2019. 04. 01. Forrás: aljazeera.com [2020. 10. 11.]

Amnesty International: Yemen: Huthi forces recruiting child soldiers for front-line combat. [online], 2017. 02. 28. Forrás: amnesty.org [2020. 10. 10.]

Arab News: KSRELIEF takes part in Warsaw Humanitarian Exhibition. [online], 2019. 06. 11. Forrás: arabnews. com [2020. 10.25.]

Arab News: Saudi Arabia steps up aid for Yemen child soldiers. [online], 2019. 08. 02. Forrás: arabnews.com [2020. 10.25.]

Asharq Al-Awsat: Houthis use Yemeni child soldiers to fuel ongoing war. [online], 2020. 03. 09. Forrás: english. aawsat.com [2020. 10. 25.]

Child Soldiers International: Child Soldiers Global Report 2001 - Yemen. [online], 2001. Forrás: refworld.org [2020. 10. 10.]

Child Soldiers International: Child Soldiers Global Report 2008 - Yemen. [online], 2008. 05. 20. Forrás: refworld. org [2020. 10. 02.]

Child Soldiers International: Yemen. Report to the Committee on the Rights of the Child in advance of Yemen's initial periodic report on the Optional Protocol to the Convention on the Rights of the Child on the involvement of children in armed conflict. [online], London, 2013. 03. Forrás: tbinternet.ohchr.org [2020. 10. 03.]

Congressional Research Service: Congress and the war in Yemen: Oversight and legislation 2015-2020. [online], 2020. 06. 19. Forrás: fas.org [2020. 10. 24.]

Cossin, Joshua: UN removes Saudi-led coalition in Yemen from child rights violators 'list of shame'. [online], 2020. 06. 17. Forrás: jurist.org [2020. 10.24.]

EG24 News: New Al-Houthi after „Al-Zainabiyat” ... „Fatimiya” to spread ideas. [online], 2020. 05. 25. Forrás: eg24.news [2020. 10. 11.]

El-Sirgany, Sarah: Firing guns, finding bodies: Life for Yemen's child soldiers. [online], 2018. 02. 03. Forrás: edition. cnn.com [2020. 10. 11.]

European Civil Protection and Humanitarian Aid Operations: Yemen. [online], Forrás: ec.europa.eu [2020. 10. 03.] 
Human Rights Council: Situation of human rights in Yemen, including violations and abuses since September 2014. A/HRC/45/CRP.7. [online], 2020. 09. 20. Forrás: ohchr.org [2020. 10. 10.]

International Organization for Least Developed Countries: Child Recruitment in Yemen: Challenges facing the United Nation Mechanisms. Geneva, 2019. [online], Forrás: ioldc.org [2020. 10. 11.]

Independent: Child soldiers from Darfur fighting at front line of war in Yemen, returned soldiers say. [online], 2018. 12. 29. Forrás: independent.co.uk [2020. 10. 24.]

International Committee of the Red Cross: Protocols Additional to the Geneva Conventions of 12 August 1949. [online], Geneva, 2010. Forrás: icrc.org [2020. 10. 03.]

Kirkpatrick, David D.: On the front line of the Saudi war in Yemen: Child soldiers from Darfur. [online], 2018. 12. 28. Forrás: nytimes.com [2020. 10. 23.]

Landay, Jonathan - Matt Spetalnick: Exclusive: Overruling his experts, Pompeo keeps Saudis off U.S. child soldiers list. [online], 2019. 06. 18. Forrás: reuters.com [2020. 10. 24.]

McKay, Hollie: Yemen's child soldiers face long road after sexual, physical abuse. [online], 2018. 07. 24. Forrás: foxnews.com [2020. 10.04.]

Michael, Maggie: These child soldiers are 'firewood' for the war in Yemen. [online], 2018. 12. 19. Forrás: globalnews. ca [2020. 10. 11.]

Middle East Eye: Huge Sudanese losses in Yemen highlight fighter's role in the conflict. [online], 2019. 11. 10. Forrás: middleeasteye.net [2020. 10. 24.]

Middle East Eye: Sudan sending hundreds of troops to Yemen via Saudi Arabia. [online], 2020. 10. 02. Forrás: middleeasteye.net [2020. 10. 24.]

Middle East Monitor: Yemen's Houthis recruit 30,000 child soldiers: Minister. [online], 2019. 07. 11. Forrás: middleeastmonitor.com [2020. 10. 03.]

NBC News: Children as young as 10 fight, kill and die in Yemen's war. [online], 2018. 12. 19. Forrás: nbcnews. com [2020. 10. 04.]

News18: Yemen's Houthi Rebels Vow to Treat and Release 64 Captive Child Soldiers. [online], 2020. 01. 27. Forrás: news18.com [2020. 10. 04.]

Numbeo: Cost of living in Yemen. [online], Forrás: Numbeo.com [2020. 10. 10.]

Office of Special Representative of the Secretary-General for Children and Armed Conflict: Five new countries endorse the Paris Commitments to end the use of children in conflict. [online], 2012. 12. 03. Forrás: childrenandarmedconflict.un.org [2020. 10. 03.]

Office of the United Nations High Commissioner for Human Rights: Optional Protocol to the Convention on the Rights of the Child on the involvement of children in armed conflict. [online], 2000. 05. 25. Forrás: ohchr. org [2020. 10.03.]

UN General Assembly Security Council: Children and armed conflict. Report of the Secretary-General. S/2019/453, 2019. [online], 2019. 06. 03. Forrás: un.org [2020. 10. 04.]

UNICEF: Yemen signs action plan to end recruitment and use of children by armed forces. [online], 2014. 05. 14. Forrás: unicef.org [2020. 10. 03.]

United Nations Treaty Collection: Convention on the Rights of the Child. [online], 1989. 11. 20. Forrás: treaties. un.org [2020. 10.03.]

Uqba, Sana: Yemen in focus: Saudi-coalition recruits child soldiers for border protection. [online], 2019. 04. 05. Forrás: english.alaraby.co.uk [2020. 10. 10.]

Uqba, Sana: Yemen in Focus: Houthis introduce martyrdom lectures into Saada school syllabus. [online], 2020.02. 26. Forrás: english.alaraby.co.uk [2020. 10. 17.]

Varfolomeeva, Anna: Houthis recruit 50,000 Yemen child soldiers in 3 months, minister says. [online], 2019. 06. 20. Forrás: thedefensepost.com [2020. 10. 04.]

Wagner, Norbert B.: Child Soldiers. [online], 2012. 07. 26. Forrás: humanitaeres-voelkerrecht.de [2020. 10. 03.]

War Child: Yemen. [online], Forrás: warchild.org.uk [2020. 10. 10.]

Wethaq Foundation for Civil Orientation: Rehabilitation of child soldiers and affected by war in Yemen. [online], Forrás: wethaq.org [2020. 10. 25.]

Yahya, Adel: Conflict generating more child soldiers. [online], 2011. 07. 20. Forrás: thenewhumanitarian.org [2020. 10. 10.] 